\title{
The Role of Virtual Office to Support Startup Companies in Indonesia
}

\author{
Milla Sepliana Setyowati ${ }^{1}$ Racha Arif Luthfi ${ }^{2}$ and Adang Hendrawan ${ }^{3}$ \\ $\left\{\underline{\text { milla.s.setyowati@gmail.com }}{ }^{1}\right.$,rachaarif21@gmail.com ${ }^{2}$ and $\underline{\text { adang.hendrawan@gmail.com }}{ }^{3}$ \} \\ Department of Fiscal Administration, Faculty of Administrative Science, Universitas Indonesia ${ }^{1,2,3}$
}

\begin{abstract}
Virtual office is a room less office but still has reception services and call forwarding services. This study examines the development and benefits of virtual office in supporting business growth, especially for start-up companies. Shifting the traditional business model towards modern business models that utilize this technology often does not require a business place such as an office to run its business. This research is a qualitative and descriptive research. Virtual office is here to answer the problem of flexibility and credibility of a company. Virtual office is one option for a company to save costs, especially companies that have a small capital structure and startup company.
\end{abstract}

Keywords: virtual office, office automation, start up company

\section{Introduction}

Virtual office is a service that provides business address rental services, reception services, call forwarding services, correspondence services, and some providers provide meeting room usage services. Virtual office is here to answer the problem of flexibility and credibility of a company. Technological advances in communication cause business activities without the need for physical presence to be very possible, especially because these business activities are business activities between countries such as buying and selling online. [1] Current technological advancements ultimately provide business operators with the freedom to run their businesses anywhere and anytime. Space and geographical location are no longer important due to the communication technology. [2]

Shifting the traditional business model towards modern business models that utilize this technology often does not require a business place such as an office to run its business. This is because they only need technology devices that are connected to the internet network to run their business and can be done anywhere and anytime. When businesses want to run their businesses under the legal entities, the need to address the business becomes important. However, for business people who do not have a permanent place of residence, renting an office or buying an office is very burdensome in terms of costs. Especially for new business people who stand with a small capital structure and do not really need an office as a place of business such as MSME or startup. Therefore, services appear that are willing to rent out business addresses with strategic and prestigious locations, namely virtual offices. In the case of using a virtual office, those who rent will get services to use virtual office addresses as company domiciles as well as correspondence addresses, reception services, and call 
forwarding services, and use of meeting rooms or business lounges in a limited time and subject to availability. Thus, this study examines the development and benefits of virtual office in supporting business growth, especially for small capital or start-up companies.

\section{Theoretical Review}

This virtual office emerged as a form of age progress in the field of technology and information. The concept of a virtual office was originally an office automation effort (office automation) that aims to help increase employee productivity. [3] Some experts define virtual office as a virtual work space which is geographically separated from its main workspace, but still connected through virtual telecommunications technology. [4]

The virtual office basically utilizes an office automation system which is a system that allows the exchange of data and information related to office secretarial and administrative activities in cyberspace automatically. Office operational activities in the virtual office concept which includes business communication are carried out through virtual communication media, such as electronic mail (e-mail) and facsimile (fax), so that the physical presence of the office is not necessary because work can be done anywhere. [5]

In its development, the definition of virtual office began to develop into a combination of correspondence and telephone number addresses that could be used as a business presence. The existence of this business can be said as a form of business address because all letters and telephone calls received by the virtual office service provider will be forwarded according to the client's instructions. [6] The Virtual Office is also described as follows [7]:

"Virtual offices combine off-site live communication, such as telephony, with address management services such as mail forwarding. Virtual offices are run by dedicated companies that provide these services to many companies from the same physical location"

When translated, the virtual office is a combination of telephone services with address management such as mail forwarding. This service can be used by many companies with the same location (same address). Based on some of these definitions it can be said that virtual office was originally an office automation to facilitate workers and improve productivity. This virtual office does not require a physical office because work can be done anywhere and anytime as long as you have virtual telecommunication technology (internet). In its development, the virtual office experienced a shift in meaning which can be interpreted as a combination of correspondence and number addresses that can be used as business addresses. This service can be used by several companies by listing the same address.

\section{Research Method}

This research is a qualitative and descriptive research so that the data collected is usually in the form of words and descriptions. [8] Therefore, a particular technique needs to be done so that the required data can be collected so that it helps researchers to analyze an issue. Data collection techniques used in this research are qualitative data collection techniques, with primary data sources coming from field research through in-depth interviews. In addition, secondary data was obtained through library research through a number of literatures. 


\section{Discussion}

The virtual office rental provides facilities in the form of leasing business addresses to be listed as company domicile and correspondence address, without the rent of office space such as rent in general. Virtual office was originally known as a serviced office. This concept was first discovered by the OmniOffices Group in 1962. The first concept was introduced about offices with services. Then, there is also an office rental mechanism for several companies introduced by a lawyer named Paul Fegen. At first, he rented a fairly large office, but the whole room was not used so he came up with an idea to rent out the unused office space. The rented office space contains office equipment and decorations so that they can be directly used by tenants. Paul Fegen leases office space to several other entrepreneurs. In 1973, Paul Fegen founded Attorney Office Management, Inc. (AOMI) which offered office rentals in Los Angeles to lawyers in Orange Country, which also became one of the forerunners of the concept of virtual office.

In 1980, John Markoff and Chris Kern gave opinions regarding the development of technology and the mobility of workers in the future. Virtual office in the future, workers will not be hampered by computer equipment or geographical location in carrying out their work. Future workers will interact easily from anywhere because of the advancement of information and communication technology. This is as revealed [9]:

"In the future virtual office, workers will no longer be constrained by computer equipment or by geographic location, according to this vision. They will be free to travel or to interact with others while communicating information reely. The office as we know it will cease to have the central importance it does today."

A similar opinion was also raised by Chris Kern, that virtual offices at least require portable computers, software, telecommunications networks (currently known as the internet) with managers, and other employees wherever they are. [10] Rapid technological development has become one of the initial thinking frameworks for the establishment of virtual offices in this decade or what is known as a flexible office that offers mobility to its users, which can work anywhere and anytime.

The need for a business address in the business world is important, not least for entrepreneurs in Indonesia. The virtual office available in Indonesia itself is currently still concentrated in the driving area of the national economy and also the capital city, namely Jakarta. Virtual office is present as an option that can be used to attempt to legalize its business in the establishment of a Limited Liability Company. This is not surprising if the virtual office itself is widely used. According to Hadi Nainggolan, Secretary General of the Indonesian Joint Office of Employers' Services Entrepreneurs (Gambbi), virtual office users almost reached 60,000 businesses. [11].

Currently there are many local companies providing virtual office services, such as Greenhub, The Executive Center, 88Office, Infiniti, IPHub, Marquee and so on. Virtual offices are located in various offices in the Jakarta area, especially those areas that are considered as the face of Jakarta's economic center, such as Sudirman, Thamrin, Kasablanka and Kuningan.

The rental price offered by virtual office services is cheap so it will not burden the company's expenses, especially companies whose capital structure is still small and also startup companies. The rental price includes receptionist and call answering services; letter collection and mail delivery; and the most important thing is a prestigious business address. 
The price of the virtual office rental for several provider companies also includes the service of using a business lounge or meeting room with limited time.

The use of virtual offices is also intended to improve the name of the company because it has an address that is in a prestigious location. Therefore, this virtual office is chosen by entrepreneurs. The registration itself is quite easy, prospective users only need to prepare the required documents such as in Infiniti's virtual office that the prospective user in the form of a company must have at least 1 person who has a Jakarta KTP and prepares the Deed of Establishment and KTP of the President Director. [12]

Although initially the use of virtual office was banned in Jakarta with the issuance of Circular of the Head of the One Stop Services of DKI Jakarta Province Number 41 / SE / 2015 concerning Domicile Certificate of Virtual Office Business Entity on November 2, 2015. However, after discussion by several parties finally the circular was revoked and replaced with a circular letter that allowed the use of virtual office services in Jakarta. On January 29, 2016 a Circular of the Head of the One Stop Service Agency Number 06 / SE / 2016 was issued concerning the Issuance of Domicile Certificates and Continued Permits for Virtual Office Users that allow entrepreneurs to use addresses in virtual office services as company domicile addresses.

Virtual office is more intended as a business presence or shows the existence of a business. In the virtual office service there is no space that is dedicated to being used all the time, but it needs to do a loan again or booking to use the virtual office provider space. This also depends on the availability of space or space in the office center and its limited time to use. This again returns to the main objective of the virtual office that provides users with a prestigious address to show the identity of a business, and not as a form of office space rental in general. Virtual office users usually use this service for the needs of administrative addresses and numbers that can actually be contacted without actually renting a room in the office.

Office rental prices also tend to be more expensive each year, especially in elite and prestigious areas that offer fantastic rental prices, causing entrepreneurs with little capital structure and tend to still be new preferring not to rent offices physically and tend to try through the internet. This shows that over time, offices are no longer the main need for running a business.

Although at present the office function can be replaced because of technological advances but without an office, a business can not be trusted by consumers or users of its services. Rozovics, a lawyer in the United States who practices international law and business, is afraid of losing his client because of his address in a residential area and causing his client to feel dissatisfied. [12] Therefore, an address that shows the place of business activity is an important part to show the company's credibility, especially the address is in a prestigious area and the economic center of a city.

For entrepreneurs who have high mobility in doing their jobs, then renting an office is not a major requirement. But because of the administrative requirements for the establishment of a business entity, a business needs to have a business address. Virtual office is an option for these entrepreneurs. This virtual office can be used for administrative purposes while at the same time providing business credibility because it seems to have an office. In addition, a virtual office that is actually a rental business address is not a problem when employers or companies work anywhere and anytime because the virtual office also provides flexibility in doing work.

Using a virtual office also saves on the costs incurred compared to physical office rent. Based on Cushman and Wakefield's research that Indonesia is the country with the most 
expensive property rental in Asia Pacific. [13] In 2012, Jakarta CBD office rental prices rose by $46 \%$. It is not surprising that virtual office is one option for a company to save costs, especially companies that have little capital structure and start-up companies. As Rotman said that utilizing a virtual office will save up to $80 \%$ of expenses for office rental costs in general. [14] Virtual office fees that are not too large compared to those issued for renting offices, employers can allocate these funds for business development needs. This is because employers have eliminated expenditures for Property Tax, maintenance costs and other costs attached to office rentals.

\section{Conclusion}

Technological developments increasingly provide ease of communication and offer efficiency, which is important for those who run businesses. Because it is supported by technological sophistication, there is flexibility in running a business, resulting in a virtual office. The virtual office phenomenon shows that business activities begin to rarely use offices as a place to run their business. The main objective of a virtual office is to provide users with a prestigious address to show the identity of a business, and not as a form of office space rental in general. Virtual office is intended as a business presence or shows the existence of a business, generally used by startup companies. Virtual office is one way that can be used as an effort to legalize its business in the establishment of a Limited Liability Company.

\section{References}

[1] Darussalam dkk. Perjanjian Penghindaran Pajak Berganda: Panduan, Interpretasi, dan Aplikasi. Jakarta: PT Dimensi International Tax. (2017).

[2] Hoffmann, E.C dkk. "ICT, Virtual Offices and Flexible Work Options: Marketing and Implementation Strategies". South African Journal of Information Management Vol 6 (4). December (2004).

[3] Raymond, McLeod dan Hendra, Teguh (Penerjemah). Sistem Informasi Manajemen, Edisi Bahasa Indonesia, Jilid 2. Jakarta: Prenhallindo. (2001).

[4] Habib, Laurence dan Cornford, Tony. "The Virtual Office and Family Life". Department of Information Systems, London School of Economics.

[5] Saliman. "Virtual Office Realitas dari Office Automation". Jurnal Universitas Negeri Yogyakarta

Vol. VII, No. 2 Hal. 124 - 137. Agustus (2007).

[6] Consulco. "Virtual Office". www.consulco.com/files/download.n653t.pdf.

[7] Workspace. "Guide to Virtual Office". www.workspace.co.uk/community/homework/growth-andstrategy/guide-to-virtual-offices.

[8] Neuman, W. Lawrence, Social Research Methods: Qualitative and Quantitative Approaches Seventh Edition. United States of America: Pearson Education Limited. (2014).

[9] Markoff, John. "Virtual Office, Can Be Almost Anywhere You Want It To", 12 Juli 1982. InfoWorld: The News Weekly for Microcomputer Users, Vol. 4, No. 27, ISSN 0199-6649. (1982).

[10] Kern, Chris. “A Virtual Office”. September. American Way, Vol. 16, No. 9. (1983).

[11] Gunawan, Hendra. "Virtual Office Kena Pajak, PERJAKBI: Semoga Melancarkan Bisnis". 8 April. http://www.tribunnews.com/bisnis/2018/04/08/virtual-office-kena-pajak-perjakbi-semoga-melancarkanbisnis. (2018).

[12] Tebo, Margaret Graham. "Virtual Office in Real Space: Many Solos Opt for Companies That Offer All the Trimmings". ABA Journal Vol. 93, No. 8. Agustus (2007). 
[13] Kompas. “Wah... Harga Sewa Kantor di Jakarta Naik!”. https://properti.kompas.com/read/2013/02/

22/13512695/wah.harga.sewa.kantor.di.jakarta.naik.

[14] Rotman, Guillermo. "Virtual Offices Help Small Firms Play Bigger". Gpsolo: Chicago 26.3.

April/May. Proquest. Pg. 37-39. (2009). 